\title{
Uji Eksperimental Pengembangan Turbin Hidrokinetik Savonius Berdasarkan Bentuk Profil Distribusi Kecepatan Aliran
}

\author{
RADITYA YUDISTIRA, DWI ANUNG NINDITO, RADEN HARYO SAPUTRA
}

Teknik Sipil Universitas Palangka Raya

Email: dwi_anungnindito@eng.upr.ac.id

\begin{abstract}
ABSTRAK
Turbin Tornado Savonius terinspirasi dari bentuk pola distribusi kecepatan yang kecil pada bagian bawah blade turbin kemudian membesar pada bagian atas blade turbin, yang bertujuan memperbesar area bidang tangkap aliran pada bagian atas turbin. Uji eksperimental dilakukan pada saluran prismatik dan membandingkan kinerja antara turbin hidrokinetik Savonius dan turbin Tornado Savonius. Berdasarkan hasil uji eksperimen, turbin Tornado Savonius memiliki performa optimum pada saat kedalaman air di saluran sama dengan tinggi turbin yang diuji coba. Bentuk blade turbin hidrokinetik Tornado Savonius mampu memperbesar area bidang tangkap aliran yang mengenai turbin, sesuai dengan bentuk distribusi kecepatan aliran untuk kondisi kedalaman yang sama dengan tinggi turbin.
\end{abstract}

Kata kunci: savonius, hidrokinetik, tornado savonius, distribusi kecepatan aliran.

\begin{abstract}
Tornado Savonius turbine inspired by velocity distribution pattern shape which small at the bottom and getting bigger the upper part of turbine blade. Such shape aims to enlarge the flow catchment area at the turbine's upper part. Experimental test performed in prismatic channel by comparing the performance of Savonius hydrokinetic turbine and Tornado Savonius turbine. Based on the result of experimental test, Tornado Savonius turbine has optimum performance at the time of water depth in channel equal to height of the examined turbine. Blade shape of Tornado Savonius hydrokinetic turbine is able to enlarge the flow catchment area in accordance with flow speed distribution shape at the same depth as turbine height.
\end{abstract}

Keywords: savonius, hydrokinetic, tornado savonius, flow velocity distribution. 


\section{PENDAHULUAN}

Menurut Fleisinger, Vesenjak dan Hriberšek (2014), turbin hidrokinetik adalah turbin yang memanfaatkan energi kinetik dari aliran air. Turbin hidrokinetik dapat diaplikasikan pada saluran air buatan (Torresi, Fortunato dan Camporeale, 2013), area pasang surut (Lago, Ponta dan Chen, 2010), laut (Gorlov, 2001) dan sungai (Khan, Iqbal dan Quaicoe, 2008). Turbin hidrokinetik dibedakan menjadi 2 jenis menurut sumbu putar porosnya, yaitu horizontal axis water turbine (HAWT) yang menggunakan beda tinggi (head) seperti turbin archimedes screw (Juliana, Weking dan Jasa, 2018) dan vertical axis water turbine (VAWT) yang menggunakan low head seperti turbin DNA yang merupakan hasil pengembangan hidrokinetik turbin gorlov (Antomo, Kamiana dan Nindito, 2020).

Pengaplikasian vertical axis water turbine (VAWT) lebih sedikit dilakukan (Hall et al., 2006) karena distribusi kecepatan aliran di penampang saluran yang kurang memaksimalkan konsep hidrokinetik turbin. Distribusi kecepatan aliran tidak sama sepanjang kedalaman saluran, semakin mendekati permukaan kecepatan aliran semakin tinggi (Nindito, 2009). Bentuk profil distribusi kecepatan aliran arah vertikal penampang saluran prismatik menunjukkan semakin mengecil mendekati dasar saluran (Wardani, Nindito dan Jaya, 2020). Perbedaan distribusi kecepatan di saluran terbuka terjadi karena adanya gesekan pada dinding sepanjang saluran, hal ini menyebabkan pembagian kecepatan yang tidak sama dalam penampang saluran (Suciana, Sumiadi dan Sisinggih, 2016).

Modifikasi pada bentuk turbin Savonius perlu dilakukan untuk mengoptimalkan prinsip profil distribusi kecepatan aliran air. Dalam studi ini dikembangkan jenis baru dari turbin hidrokinetik Savonius yang dinamakan turbin Tornado Savonius. Dimensi lengkung blade turbin Tornado Savonius disesuaikan dengan bentuk profil distribusi kecepatan aliran di $0,2 h$; $0,6 h$; dan $0,8 h$ dari kedalaman aliran. Tujuan studi ini adalah mengetahui kinerja yang dihasilkan turbin Tornado Savonius.

Distribusi kecepatan aliran ditentukan dari beberapa faktor seperti bentuk penampang saluran dan kekasaran saluran. Kecepatan maksimum pada permukaan bebas terjadi pada saluran yang mempunyai arus yang besar atau deras dan dangkal serta dasar saluran yang licin (Suciana, Sumiadi dan Sisinggih, 2016).

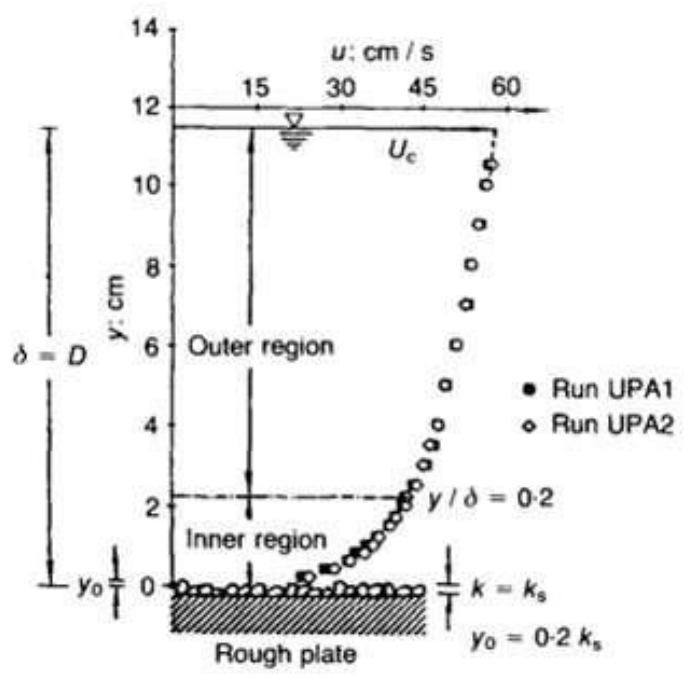

Gambar 1. Profil kecepatan penampang rata-rata pada rough plate (Kironoto dan Graf, 1994)

RekaRacana - 2 
Gambar 1 menunjukkan distribusi kecepatan yang kecil pada dasar saluran kemudian meningkat pada bagian atas saluran (Kironoto dan Graf, 1994). Nindito, Istiarto dan Kironoto (2009) melakukan pemodelan numerik tiga dimensi kecepatan aliran air di saluran kantong lumpur. Kecepatan aliran semakin mendekati tepi saluran semakin kecil dan kecepatan maksimum terjadi pada bagian tengah saluran $(x / B=1 / 2)$.

Turbin Savonius (Savonius dan Finland, 1931) memiliki desain yang sederhana dan dapat berputar pada semua arah aliran.

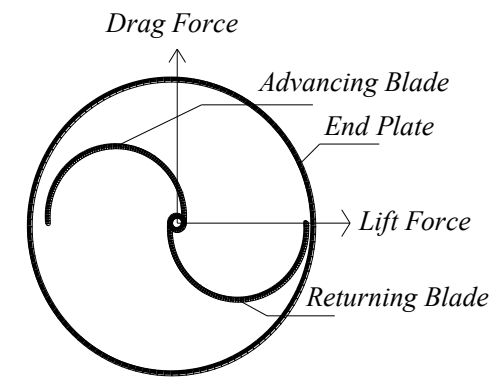

(a)

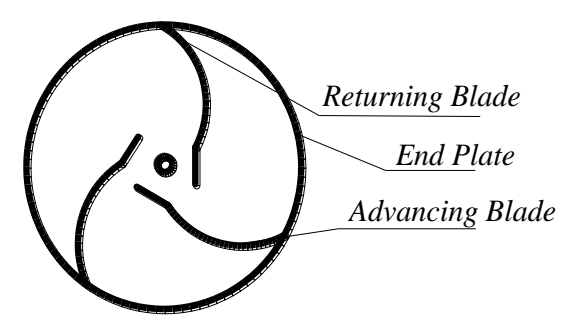

(c)

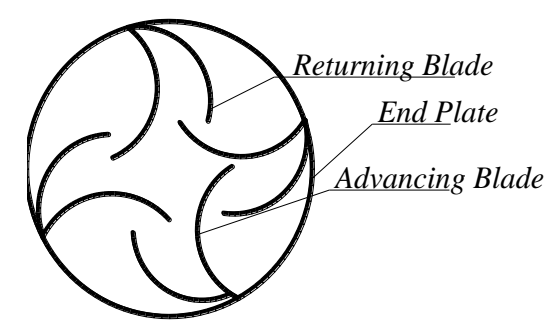

(e)

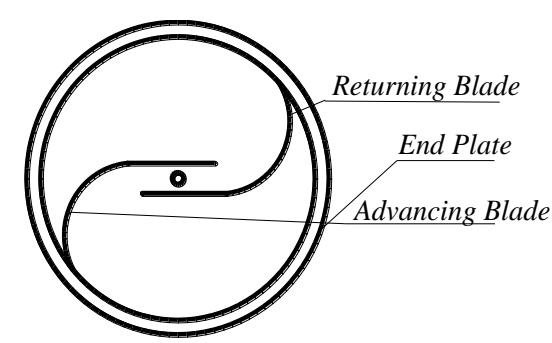

(b)

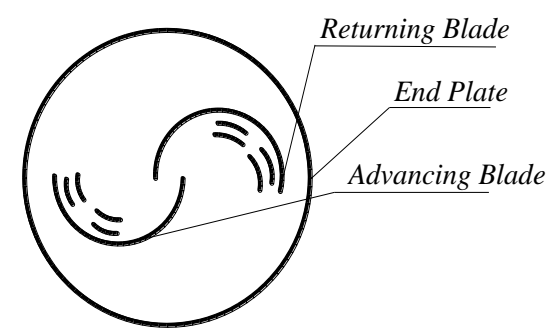

(d)

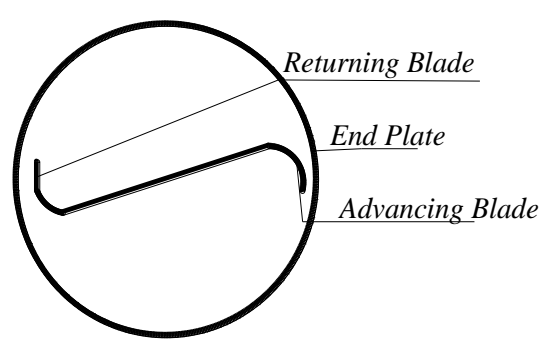

(f)

Gambar 2. Komponen turbin Savonius: a. Savonius (Savonius dan Finland, 1931), b. Bach Modifikasi (Roy, Mukherjee dan Saha, 2014), c. Fish-Ridged(Song et al., 2013), d. Multiple Quarter Semicircular (Sharma dan Sharma, 2016), e. Bronzinus (Muscolo dan Molfino, 2014), f. Spline (Mari, Venturini dan Beyene, 2017)

Berdasarkan Gambar 2 menunjukkan bahwa desain turbin Savonius terdiri atas dua bagian utama yaitu returning blade dan advancing blade yang berfungsi sebagai daerah tangkapan gaya untuk memutar turbin. Dua buah end plate berfungsi sebagai tempat meletakkan blade. Penggunaan end plate di atas dan bawah rotor meningkatkan koefisien daya sebesar $36 \%$ dibandingkan dengan tanpa end plates (Jeon et al., 2015).

Menurut Alejandro Franco et al., (2017), gaya drag didefinisikan sebagai gaya sejajar dengan arah dari aliran yang masuk, sedangkan gaya lift merupakan gaya yang bekerja tegak lurus terhadap arah aliran. Turbin Savonius memiliki desain blade yang dipengaruhi 
gaya drag, sedangkan bentuk blade turbin Darrieus dan Gorlov dipengaruhi gaya lift. Berdasarkan konsep gaya lift, perbedaan tekanan antara permukaan blade menghasilkan gaya lift yang membuat turbin berputar. Gaya lift memiliki self-starting yang kurang baik, sedangkan gaya drag memiliki self-starting yang lebih baik (Roy dan Saha, 2013).

Untuk meningkatkan kinerja turbin Savonius, beberapa studi melakukan inovasi untuk membuat bentuk blade yang berbeda.

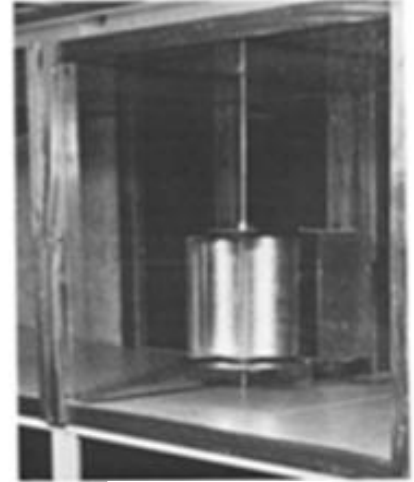

(a)

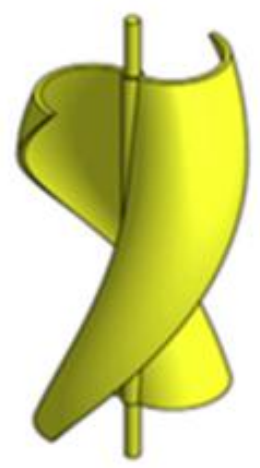

(d)

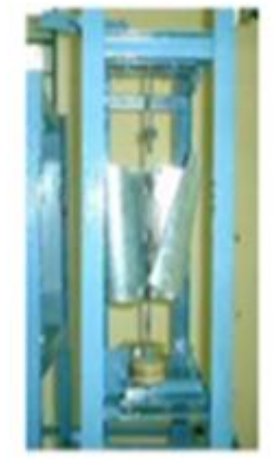

(b)

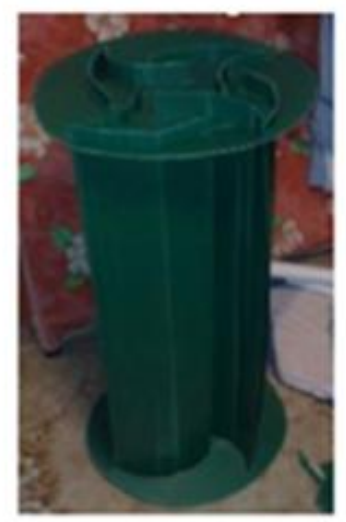

(e)

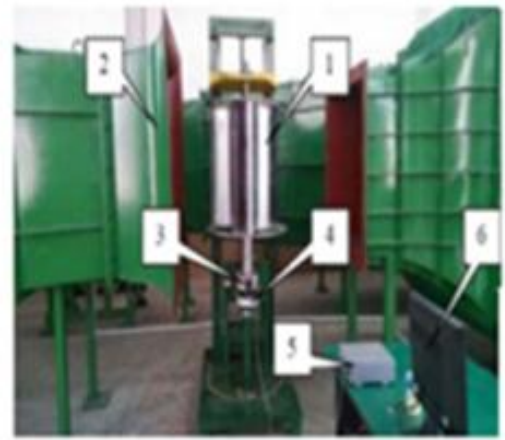

(c)

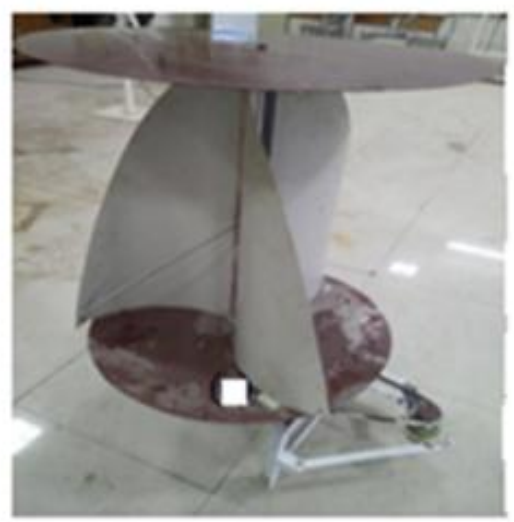

(f)

Gambar 3. Inovasi desain turbin Savonius (a) Semicircular (Alexander dan Holownia, 1978), (b) Twisted (Grinspan, Saha dan Mahanta, 2004), (c) Fish-ridged (Song et al., 2013), (d) Helical (Jeon et al., 2015), (e) Bronzinus (Muscolo dan Molfino, 2014), (f) Savonius Modifikasi (Baredar dan Gupta, 2019)

Bentuk twisted (Gambar $\mathbf{3 b}$ ) melakukan perbandingan secara eksperimental terhadap turbin Semicircular. Hasil desain turbin twisted meningkatkan torsi positif sebesar $20 \%$ (Grinspan dan Mahanta, 2004). Fish-ridged (Gambar 3c) mempunyai bentuk yang lebih sederhana dan performa yang lebih baik (Song et al., 2013). Turbin bentuk Helical Savonius (Gambar 3d) dapat meningkatkan $C_{P}$ sebesar 8,6\% dibandingkan dengan turbin klasik Savonius. Turbin Bronzinus (Gambar $3 \mathbf{3 e}$ ) memiliki kinerja $C_{P}$ yang lebih tinggi dari pada turbin Savonius bentuk Semicircular. Savonius modifikasi (Gambar 3f) dapat mereduksi kebisingan sebesar 8-9\% pada saat turbin berputar. 
Tabel 1. Hasil studi kinerja turbin Savonius berdasarkan hubungan Coefficient of Power $\left(C_{P}\right)$ dan Tip Speed Ratio $(\lambda)$

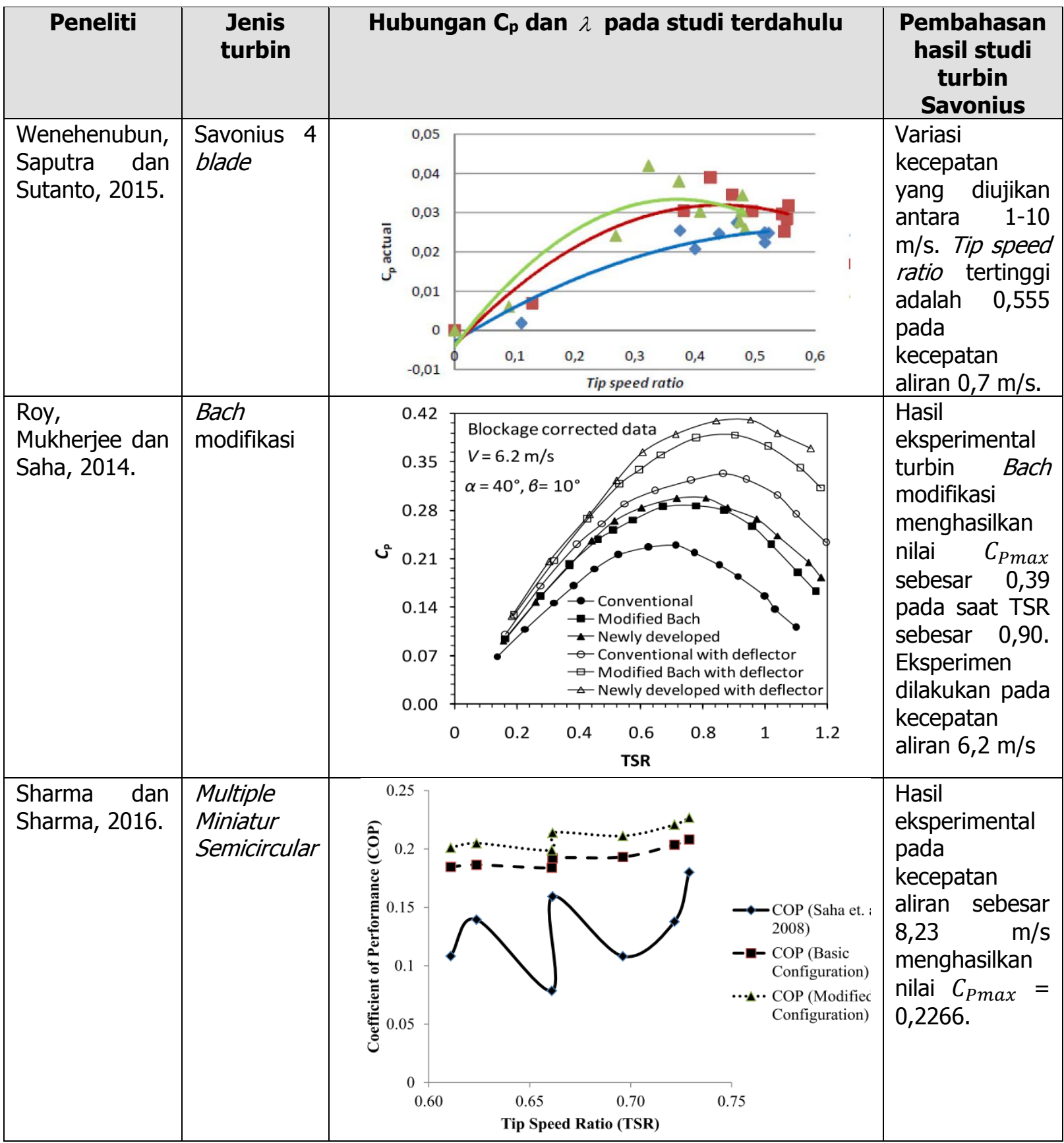

Perhitungan uji eksperimental pengembangan turbin hidrokinetik Savonius diamati dengan melihat nilai tip speed ratio $(\lambda)$ dan Coeffisient of Power $\left(C_{p}\right)$ (Elbatran, Ahmed dan Shehata, 2017). Tip speed ratio $(\lambda)$ dan Coeffisient of Power $\left(C_{p}\right)$ dapat dihitung dengan Persamaan 1:

$\omega=\frac{2 \pi . \mathrm{n}}{60 \mathrm{detik}}, \mathrm{C} \tau=\frac{4 \tau}{\rho \mathrm{v}^{2} \mathrm{D}^{2} \mathrm{H}}, \lambda=\frac{\omega . \mathrm{D}}{2 . \mathrm{v}}, \quad \mathrm{C}_{\mathrm{p}}=\lambda \mathrm{C} \tau$

dengan D adalah diameter turbin [m]; v adalah kecepatan aliran air [m/detik]; $\mathrm{n}$ adalah jumlah putaran turbin; $\omega$ adalah kecepatan sudut [rad/detik]; $\tau$ adalah torsi $[\mathrm{Nm}] ; \rho$ adalah densitas air $\left[\mathrm{kg} / \mathrm{m}^{3}\right]$; dan $\mathrm{H}$ adalah tinggi turbin $[\mathrm{m}]$. 
Tabel 2. Perbandingan Kinerja Berbagai Profil Blade Turbin Savonius

\begin{tabular}{lccl}
\hline \multicolumn{1}{c}{ Bentuk Blade } & $\boldsymbol{C}_{\boldsymbol{P m a x}}$ & TSR $_{\text {optimal }}$ & \multicolumn{1}{c}{ Referensi } \\
\hline Semicircular & 0,17 & $0,9-1,0$ & (Ogawa, Yoshida dan Yokota, 1989) \\
\hline Bach & 0,178 & 0,8 & (Kacprzak, Liskiewicz dan Sobczak, 2013) \\
\hline Spline & 0,2477 & 1,2 & (Mari, Venturini dan Beyene, 2017) \\
\hline Helical & 0,2 & 0,71 & (Kamoji, Kedare dan Prabhu, 2009) \\
\hline Airfoil shape & 0,22 & $0,7-0,9$ & (Tartuferi et al., 2015) \\
\hline Multiple quarter semicircular & 0,2266 & 0,74 & (Sharma dan Sharma, 2016) \\
\hline
\end{tabular}

Tabel 2 menunjukkan perbandingan kinerja profil blade turbin hidrokinetik Savonius yang telah dimodifikasi. Bentuk blade semicircular memiliki nilai Coefficient of Power $\left(\mathrm{C}_{\mathrm{p}}\right)$ terendah dibandingkan dengan bentuk turbin Savonius modifikasi lainnya sehingga banyak peneliti yang membandingkan bentuk blade inovasi yang dilakukan dengan bentuk semicircular.

\section{METODE PENGUJIAN}

Gambar 4 menunjukkan skema dalam pengujian turbin hidrokinetik Tornado Savonius yang merupakan hasil pengembangan turbin hidrokinetik Savonius berdasarkan bentuk profil distribusi kecepatan aliran. Pengujian ini dilakukan pada saluran prismatik (flume). Variasi kecepatan aliran $(v)$ dihasilkan dari beda tinggi $\left(H_{\text {tandon }}\right)$ antara elevasi permukaan air di tandon dengan permukaan air di saluran. Movable weir adalah alat yang berfungsi mempertahankan ketinggian air saluran yang digunakan pada saat pengujian. Point gauge adalah alat pengukur ketinggian aliran air pada saat pengujian. Nilai kecepatan aliran pada uji eksperimental turbin Tornado Savonius diukur menggunakan alat current meter pada kedalaman aliran $0,2 h ; 0,6 h$; dan 0,8h dari permukaan air. Pengukuran kecepatan aliran dilakukan pada bagian tengah saluran. Rotasi Per Menit (RPM) diukur dengan menggunakan alat tachometer. Nilai gaya diukur dengan menggunakan neraca pegas. Nilai torsi $(\tau)$

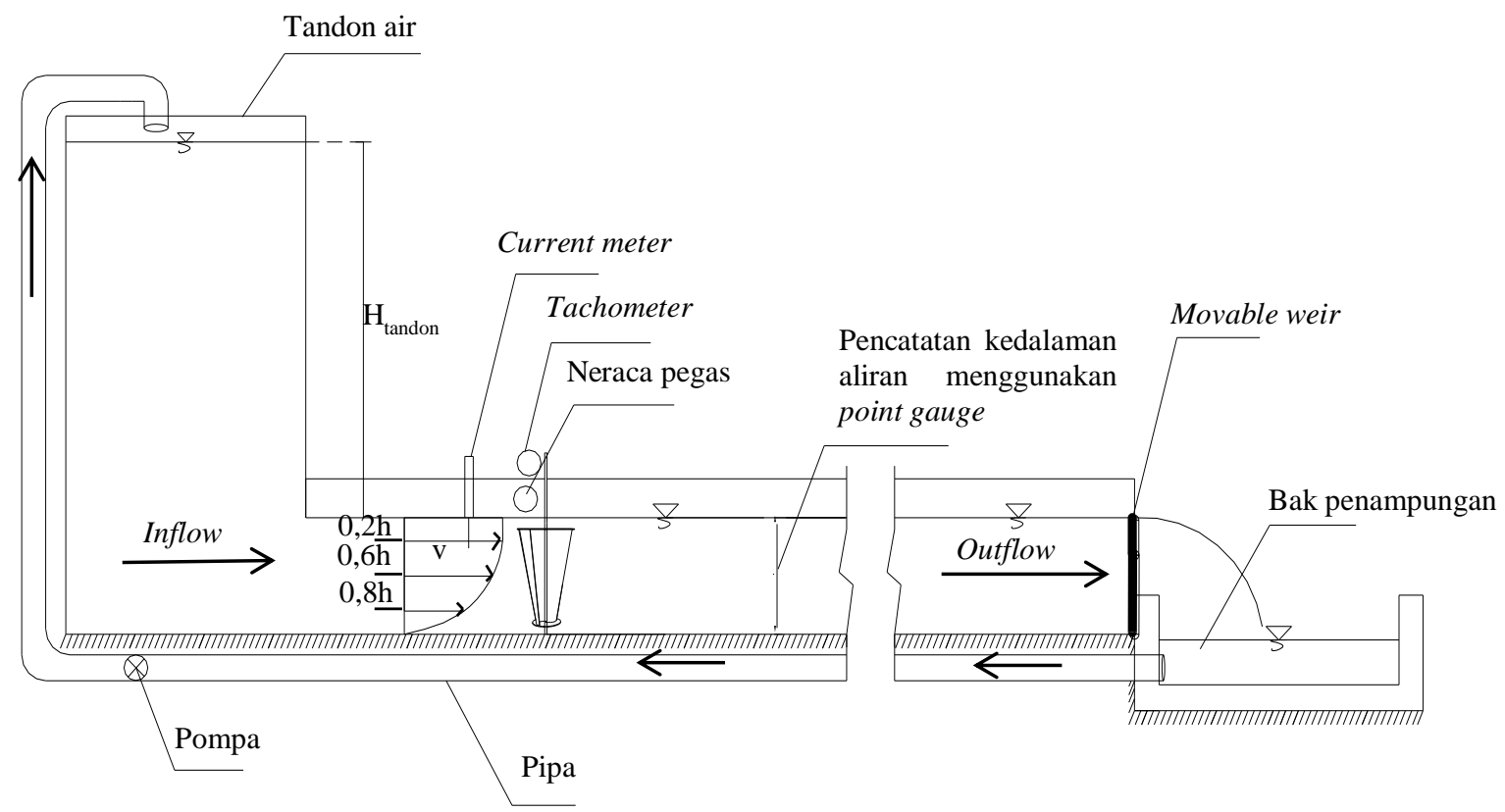

didapat dari perhitungan nilai gaya [N] dikali dengan panjang lengan gaya [m].

Gambar 4. Skema pengujian turbin Tornado Savonius pada saluran prismatik 


\section{HASIL DAN PEMBAHASAN}

\subsection{Desain turbin hidrokinetik Tornado Savonius}

Desain turbin hidrokinetik Tornado Savonius diadaptasi dari bentuk profil distribusi kecepatan aliran yang besar pada bagian atas dan mengecil pada bagian bawah. Pada saat berputar, bentuk turbin Tornado Savonius menyerupai bentuk angin tornado yang kecil pada bagian bawah end plate dan mulai membesar pada bagian atas end plate yang dapat dilihat pada Gambar 5.

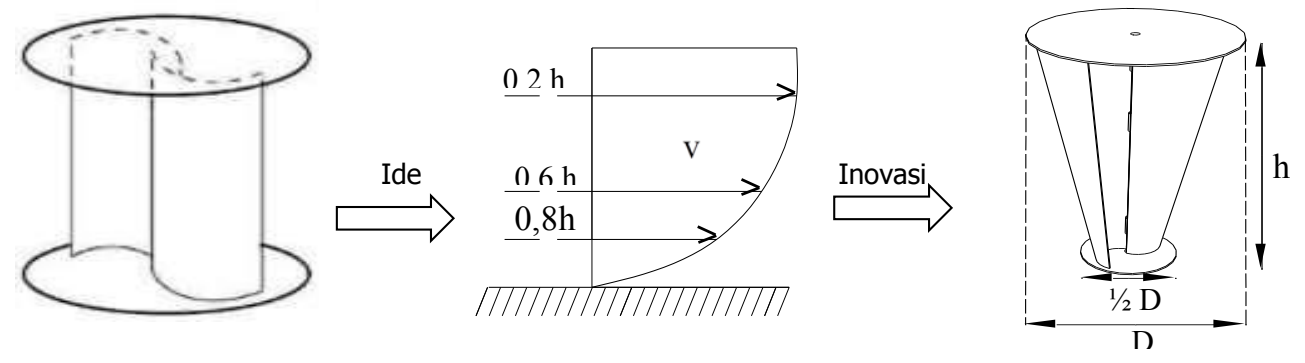

Gambar 5. Pengembangan desain turbin Savonius menjadi Tornado Savonius

Pembesaran pada bagian atas blade turbin Tornado Savonius bertujuan agar meningkatkan luas bidang tangkap energi kinetik yang dihasilkan oleh aliran air sesuai bentuk distribusi kecepatan.

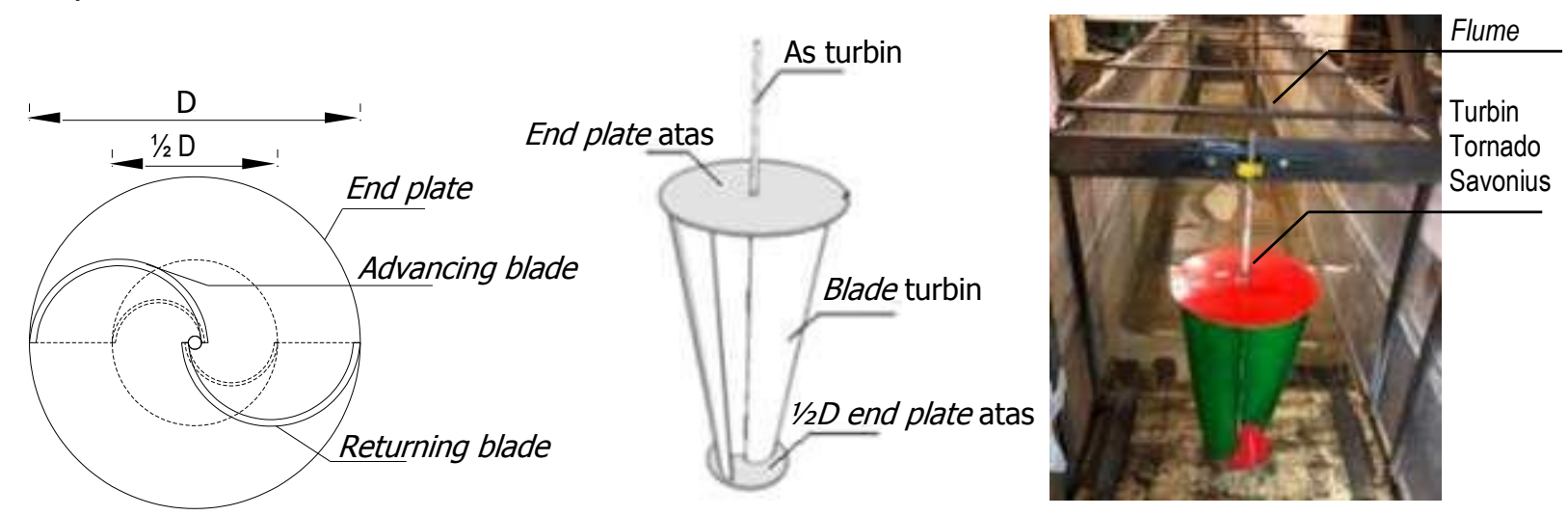

Gambar 6. Desain dan dimensi turbin Tornado Savonius

Gambar 6 menunjukkan komponen dan dimensi turbin Tornado Savonius dan posisi turbin pada saat uji eksperimen dalam saluran prismatik (flume).

Tabel 3. Spesifikasi turbin Tornado Savonius

\begin{tabular}{lc}
\hline \multicolumn{1}{c}{ Komponen Turbin } & Dimensi \\
\hline Tinggi turbin $[\mathrm{cm}]$ & 38 \\
\hline Jumlah blade turbin [buah] & 2 \\
\hline Diameter end plate bagian atas $[\mathrm{cm}]$ & 25 \\
\hline Diameter end plate bagian bawah $[\mathrm{cm}]$ & 12,5 \\
\hline Diameter as turbin [cm] & 1 \\
\hline Tinggi as turbin $[\mathrm{cm}]$ & 75 \\
\hline
\end{tabular}

Tabel 3 menunjukkan komponen turbin Tornado Savonius dan dimensi yang digunakan pada saat melakukan pengujian eksperimental. 


\subsection{Kinerja Turbin Tornado Savonius}
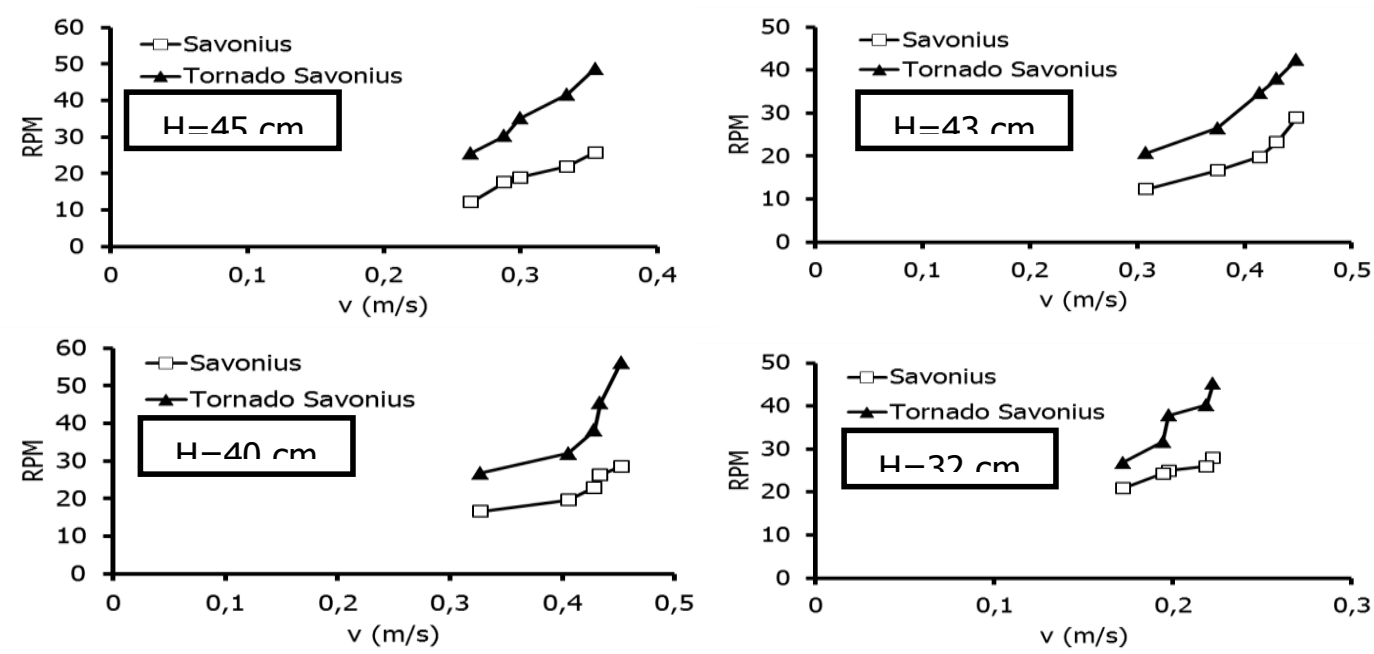

\section{Gambar 7. Hubungan antara (RPM) dan kecepatan aliran (v) turbin Savonius dan turbin Tornado Savonius}

Gambar 7 menunjukkan hasil pengujian turbin Savonius dan Tornado Savonius pada masing-masing kedalaman aliran pengukuran $(H) 32 \mathrm{~cm}, 40 \mathrm{~cm}, 43 \mathrm{~cm}$ dan $45 \mathrm{~cm}$. Pengujian dilakukan pada kecepatan aliran $(v)$ sebesar $0,172-0,453 \mathrm{~m} / \mathrm{s}$. Pada kecepatan tersebut turbin Savonius menghasilkan nilai Rotasi Per Menit (RPM) sebesar 12,2-28,9 sedangkan nilai RPM turbin Tornado Savonius sebesar 20,7-56,1. Berdasarkan nilai tersebut turbin Tornado Savonius memiliki kinerja yang lebih baik dibandingkan dengan turbin Savonius dari nilai RPM.
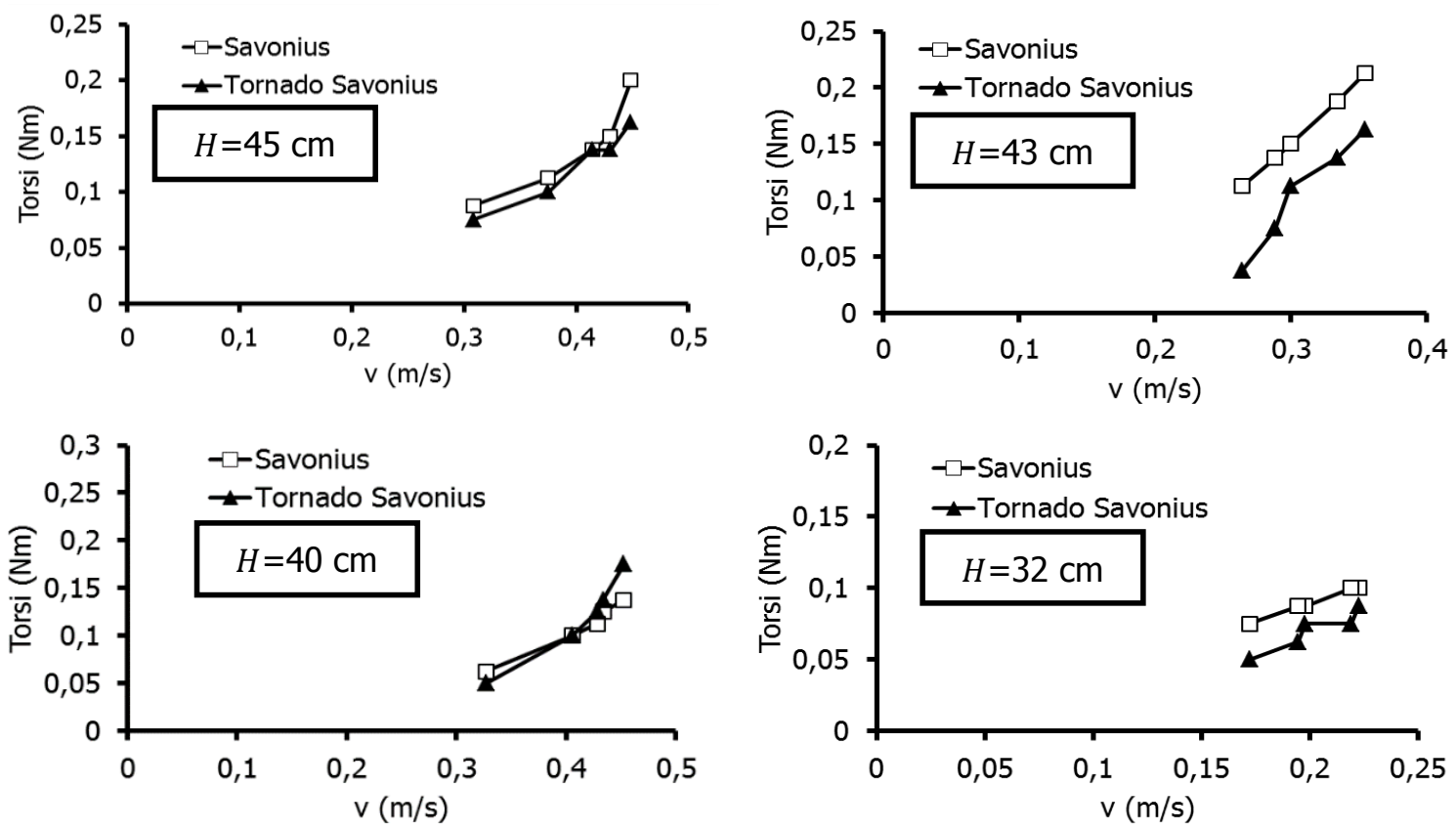

Gambar 8. Hubungan antara torsi $(\tau)$ dan kecepatan aliran $(v)$ turbin Savonius dan turbin Tornado Savonius 
Gambar 8 menunjukkan nilai torsi $(\tau)$ pada turbin Savonius dan turbin Tornado Savonius dari pengujian pada variasi kecepatan aliran $(v)$ antara $0,172-0,453 \mathrm{~m} / \mathrm{s}$. Nilai torsi $(\tau)$ yang dihasilkan turbin Savonius adalah $0,063-0,213 \mathrm{Nm}$ dan nilai torsi $(\tau)$ yang dihasilkan oleh turbin Tornado Savonius adalah 0,038-0,175 Nm. Berdasarkan Gambar 8 terlihat ratarata performa turbin Tornado Savonius lebih rendah dibandingkan dengan turbin Savonius dari sisi perolehan nilai torsi $(\tau)$. Pada kondisi kedalaman air yang sama dengan tinggi turbin, performa torsi turbin Tornado Savonius lebih unggul dari pada turbin Savonius. Hal ini ditunjukkan dari gradien perubahan kecepatan terhadap torsi turbin Tornado Savonius lebih tinggi dari turbin Savonius.

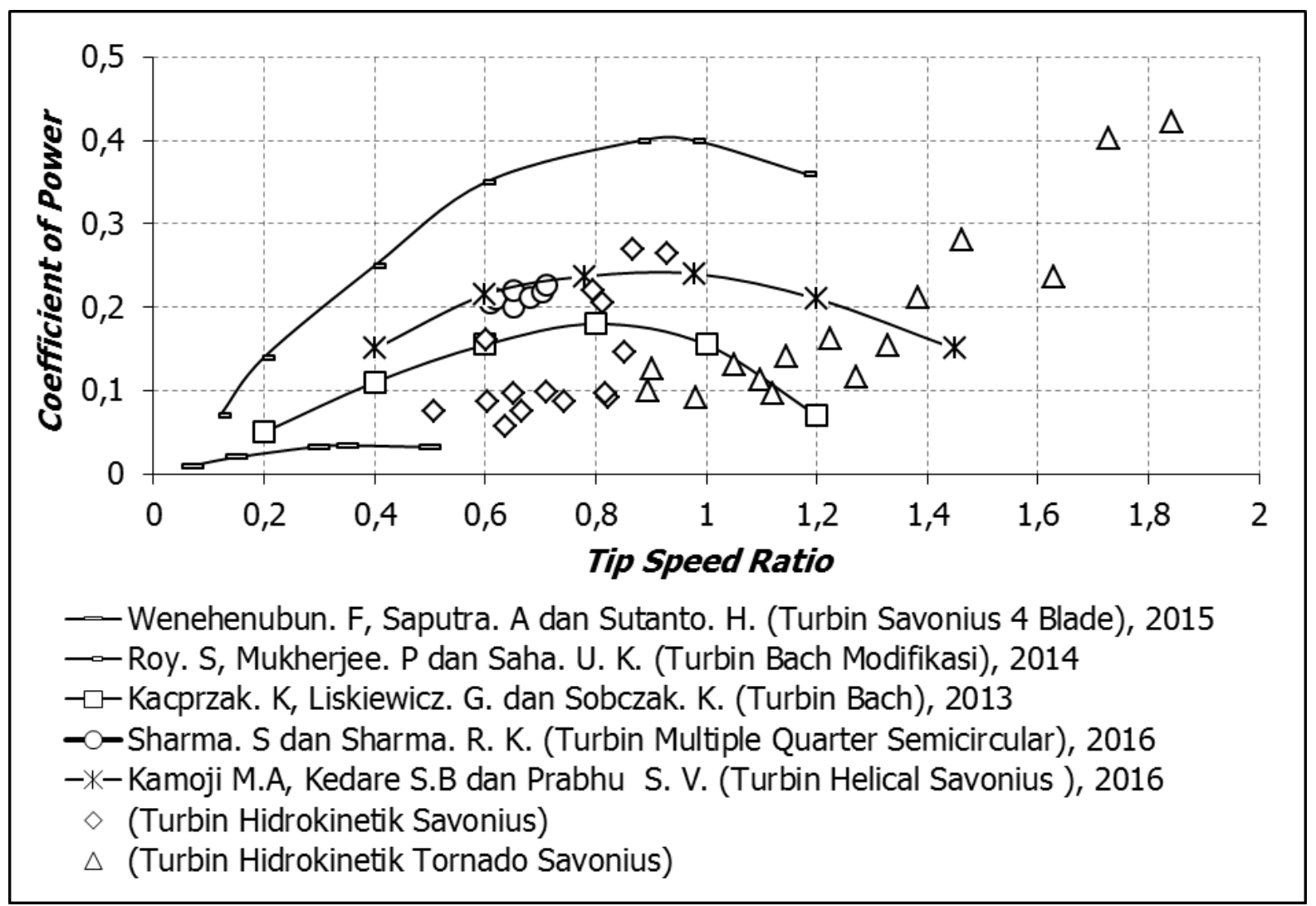

\section{Gambar 9. Perbandingan tip speed ratio $(\lambda)$ dan Coefficient of Power $\left(C_{P}\right)$ turbin Tornado Savonius dengan studi sebelumnya}

Gambar 9 menunjukkan bahwa turbin Tornado Savonius memiliki nilai Coefficient of Power $\left(C_{P}\right)$ sebesar 0,091-0,422 dan tip speed ratio $(\lambda)$ sebesar $0,895-1,843$. Lebih tinggi dibandingkan nilai $C_{P}$ dan $\lambda$ turbin Savonius dengan nilai Coefficient of Power $\left(C_{P}\right)$ sebesar $0,057-0,270$ pada rentang tip speed ratio $(\lambda)$ sebesar $0,508-0,929$. Hasil perbandingan performa turbin Tornado Savonius menghasilkan pola grafik yang tidak jauh berbeda dengan multiple quarter semicircular (Sharma dan Sharma, 2016). Turbin Tornado Savonius memiliki $C_{P}$ yang lebih tinggi dari pada Savonius 4 blade $\left(C_{P \max }=0,033\right)$ (Wenehenubun, Saputra dan Sutanto, 2015), bach modifikasi $\left(C_{P \max }=0,4\right)$ (Roy, Mukherjee dan Saha, 2014), bach $\left(C_{P \max }=0,178\right)$, (Kacprzak, Liskiewicz dan Sobczak, 2013), dan Helical Savonius $\left(C_{P \max }=\right.$ 0,2) (Kamoji, Kedare dan Prabhu, 2009). Hal ini dikarenakan turbin Tornado Savonius dapat memaksimalkan gaya lift pada kedalaman saluran yang sama dengan tinggi turbin, sedangkan turbin Savonius peneliti sebelumnya mengandalkan gaya drag. 


\section{KESIMPULAN}

Perubahan bentuk blade turbin Savonius dengan memperkecil ukuran blade pada bagian bawah sehingga bentuknya serupa dengan bentuk distribusi kecepatan aliran merupakan inovasi dari studi ini. Turbin Tornado Savonius menghasilkan Coefficient of Power $\left(C_{P}\right)$ sebesar $0,091-0,422$ pada saat range tip speed ratio $(\lambda) 0,895-1,843$. Nilai ini lebih besar jika dibandingkan dengan turbin Savonius yang memiliki nilai Coefficient of Power $\left(C_{P}\right)$ $0,057-0,270$ pada saat nilai tip speed ratio $(\lambda)$ sebesar $0,508-0,929$. Pada rentang kecepatan aliran $0,172-0,453 \mathrm{~m} / \mathrm{s}$; perubahan bentuk blade yang mengikuti pola distribusi kecepatan aliran membuat nilai Rotasi Per Menit ( RPM) turbin Tornado Savonius lebih besar dibandingkan dengan turbin Savonius, namun mengalami penurunan kinerja pada torsi $(\tau)$ yang dihasilkan. Pengujian yang dilakukan pada blade bagian bawah dengan ukuran berbeda yaitu $1 / 4$ atau $3 / 4$ dari diameter turbin menjadi hal yang menarik untuk studi selanjutnya.

\section{DAFTAR RUJUKAN}

Alejandro, F. J., Carlos, J. J., Carbajal, A., \& Toledano-Ayala, M. (2017). Shape Morphing Mechanism for Improving Wind Turbines Performance. Journal of Energy Resources Technology, Transactions of the ASME, 139(5).

Alexander, A. J., \& Holownia, B. P. (1978). Wind Tunnel Tests on A Savonius Rotor. Journal of Wind Engineering and Industrial Aerodynamics, 3(4), 343-351.

Antomo, T., Kamiana, I. M., \& Nindito, D. A. (2020). Analisis Pengembangan Hidrokinetik Turbin Gorlov Akibat Penambahan Luas Bidang Tangkap. Teknika: Jurnal Sains Dan Teknologi, 16(2), 159.

Baredar, P., \& Gupta, B. (2019). Performance Estimation of Modified Savonius Wind Turbine Blade Profile. SSRN Electronic Journal.

Elbatran, A. H., Ahmed, Y. M., \& Shehata, A. S. (2017). Performance Study of Ducted Nozzle Savonius Water Turbine, Comparison with Conventional Savonius Turbine. Energy, 134, 566-584.

Fleisinger, M., Vesenjak, M., \& Hriberšek, M. (2014). Flow driven analysis of a darrieus water turbine. Strojniski Vestnik/Journal of Mechanical Engineering 60(12), 769-776. Assoc. of Mechanical Eng. and Technicians of Slovenia.

Gorlov, A. M. (2001). Tidal Energy. In Encyclopedia of Ocean Sciences.

Grinspan, A. S., Saha, U. K., \& Mahanta, P. (2004). Experimental Investigation of Twisted Bladed Savonius Wind Turbine Rotor. International Energy Journal, 5(1), 1-9.

Hall, D. G., Reeves, K., Brizzee, J., Lee, R., Carroll, G., \& Sommers, G. (2006). Feasibility Assessment of the Water Energy Resources of the United States for New Low Power and Small Hydro Classes of Hydroelectric Plants. US Department of Energy.

Jeon, K. S., Jeong, J. I., Pan, J. K., \& Ryu, K. W. (2015). Effects of End Plates With Various Shapes and Sizes on Helical Savonius Wind Turbines. Renewable Energy, 79(1), 167-176.

Juliana, I. P., Weking, A. I., \& Jasa, L. (2018). Pengaruh Pengaruh Sudut Kemiringan Head Turbin Ulir Terhadap Daya Putar Turbin Ulir Dan Daya Output Pada Pembangkit Listrik Tenaga Mikro Hidro. Majalah IImiah Teknologi Elektro, 173), 393.

Kamoji, M. A., Kedare, S. B., \& Prabhu, S. V. (2009). Performance Tests on Helical Savonius Rotors. Renewable Energy, 34, 521-529.

Kacprzak, K., Liskiewicz, G. \& Sobczak, K. (2013). Numerical investigation of conventional and modified Savonius wind turbines. Renewable Energy, Elsevier Ltd, 60, pp. 578-585.

Khan, M. J., Iqbal, M. T., \& Quaicoe, J. E. (2008). River Current Energy Conversion Systems: Progress, Prospects and Challenges. Renewable and Sustainable Energy Reviews. 
Kironoto, B. A., \& Graf, W. H. (1994). Turbulence Characteristics in Rough Uniform OpenChannel. Proceedings of the Institution of Civil Engineers: Water, Maritime and Energy, $106,333-344$.

Lago, L. I., Ponta, F. L., \& Chen, L. (2010). Advances and Trends in Hydrokinetic Turbine Systems. Energy for Sustainable Development, 14(4), 287-296.

Mari, M., Venturini, M., \& Beyene, A. (2017). A Novel Geometry For Vertical Axis Wind Turbines Based on The Savonius Concept. Journal of Energy Resources Technology, 139(6).

Muscolo, G. G., \& Molfino, R. (2014). From Savonius to Bronzinus: A Comparison Among Vertical Wind Turbines. Energy Procedia, 50, 10-18.

Nindito, D. A. (2009). Pengaruh Profil Distribusi Kecepatan Terhadap Hasil Perhitungan Kecepatan Gesek Pada Aliran Bersedimen di Lokasi Pengukuran Arah Transversal Saluran Tampang Segiempat. Jurnal Proteksi, 1(1), 8-15.

Nindito, D. A., Istiarto, I., \& Kironoto, B. A. (2008). Simulasi Numeris Tiga Dimensi Kantong Lumpur Bendung Sapon. Civil and Environmental Engineering Departmen Faculty of Engineering Gadjah Mada University, 18, 712-724.

Ogawa, T., Yoshida, H., \& Yokota, Y. (1989). Development of Rotational Speed Control Systems for a Savonius-Type Wind Turbine. Journal of Fluids Engineering, Transactions of the ASME, 111, 53-58.

Roy, S., Mukherjee, P., \& Saha, U. K. (2014). Aerodynamic Performance Evaluation of A Novel Savonius-Style Wind Turbine Under an Oriented Jet. ASME 2014 Gas Turbine India Conference, GTINDIA 2014.

Roy, S., \& Saha, U. K. (2013). Review of Experimental Investigations into the Design, Performance and Optimization of the Savonius Rotor. Proceedings of the Institution of Mechanical Engineers, Part A: Journal of Power and Energy, 22入4), 528-542.

Savonius, S. J., \& Finland, H. (1931). Mechanical Engineering. Mechanical Engineering, 53(5), 331-338.

Sharma, S., \& Sharma, R. K. (2016). Performance Improvement of Savonius Rotor Using Multiple Quarter Blades - A CFD Investigation. Energy Conversion and Management, 127, 43-54.

Song, L., Yang, Z. X., Deng, R. T., \& Yang, X. G. (2013). Performance and Structure Optimization For a New Type of Vertical Axis Wind Turbine. International Conference on Advanced Mechatronic Systems, ICAMechS, 687-692.

Suciana, A. T., Sumiadi, \& Sisinggih, D. (2016). Kajian Distribusi Kecepatan Aliran Sebelum dan Sesudah Belokan di Saluran Terbuka Menggunakan Acoustic Doppler Velocimeter (ADV). Jurnal Teknik Pengairan Konsentrasi Perencanaan Bangunan Air.

Tartuferi, M., D'Alessandro, V., Montelpare, S., \& Ricci, R. (2015). Enhancement of Savonius Wind Rotor Aerodynamic Performance: A Computational Study of New Blade Shapes and Curtain Systems. Energy, 79, 371-384.

Torresi, M., Fortunato, B., \& Camporeale, S. M. (2013). Numerical Investigation of a Darrieus Rotor For Low-head Hydropower Generation. Procedia - Procedia Computer Science, 19, 728-735.

Wardani, C. S., Nindito, D. A., \& Jaya, A. R. (2020). Inovasi Dan Desain Turbin Hidrokinetik Darrieus Berdasarkan Bentuk Distribusi Kecepatan Aliran. Media IImiah Teknik Sipil, $9(1), 32-43$.

Wenehenubun, F., Saputra, A., \& Sutanto, H. (2015). An Experimental Study on The Performance of Savonius Wind Turbines Related With The Number of Blades. Energy Procedia, 68, 297-304. 